\title{
Survey of ethno-veterinary medicinal plants at se- lected districts of Harari Regional State, Eastern Ethiopia
}

\author{
Akil Usmane ${ }^{1}$, Tadesse Birhanu ${ }^{1 *}$, Mohammed Redwan ${ }^{2}$, Edao Sado ${ }^{3}$ and Dereje \\ Abera $^{1}$ \\ ${ }^{1}$ School of Veterinary Medicine, College of Medical and Health Sciences, Wollega University, P.O. \\ Box 395, Nekemte, Ethiopia \\ ${ }^{2}$ Livestock Production Development Agency, Harari Regional State Agricultural Office, Animal \\ Health Extension Unit \\ ${ }^{3}$ Department of Pharmacy, Pharmacoepidemiology and Social pharmacy Unit, Wollega Univer- \\ sity, Wellega, Ethiopia \\ *Corresponding author: School of Veterinary Medicine, College of Medical and Health Sciences, \\ Wollega University, P.O. Box 395, Nekemte, Ethiopia, Email:drbirhan@yahoo.com \\ http://dx.doi.org/10.4314/evj.v20i1.1
}

\begin{abstract}
The survey of ethno-veterinary medicinal plants was conducted from November, 2014 to April, 2015 at selected districts of Harari Regional State, eastern Ethiopia. The aim of the study was to identify and document medicinal plants and the associated ethno-medicinal knowledge of the local community. Semi-structured interview, guided field observation, group discussion and market survey were used to collect the required data. Informant consensus method and group discussion were conducted for crosschecking and verification of the information. Both descriptive statistics and quantitative methods were used for data analysis. About 46 plant species belonging to 33 families were identified and documented based on the local claims of the plants. Majority plant taxa were collected from the wild (54.4\%) followed by domestic once (24\%). Among these plant families, Fabaceae, Solanaeceae and Euphorbiaceae were commonly used to treat Equine colic, retained placenta and Black leg respectively. The most frequently used plant parts were reported to be the leaves (37\%) and then the roots (30.4\%). The condition of preparation was in the fresh form (82.5\%) and fresh/dry form (17.5\%). Oral administration (65.3\%) was the most common route of administration. In conclusion, the participants have a wealth of indigenous knowledge about plant medicines for treating their livestock but, agricultural expansion was the major threats to medicinal plants in the study area. Thus, awareness creation should be done in order to conserve and document the plants.
\end{abstract}


Keywords: Ethno-veterinary, Medicinal plants, Indigenous knowledge, Harari Regional State

\section{Introduction}

In Africa, up to $80 \%$ of the population use traditional medicine for primary health care (Sinha et al., 2002; Haile Yineger, 2005). In Ethiopia, plant remedies are still the most important and sometimes the only sources of therapeutics for nearly $80 \%$ of human and more than $90 \%$ in livestock population (Gebrehiwot Mengistu, 2004; Tadesse Birhanu and Dereje Abera, 2015). Despite their vital role in catering for the health of human and livestock population, large part of the knowledge of ethno medicinal plants is on the verge of irreversible loss and declining to deterioration due to oral passage of herbal heritage from generation to generation verbally rather than in writings (Tadesse Birhanu et al., 2014).

Traditional health practitioners have been made remedies from plants that play an important role to treat both animals and human diseases. The use of ethno-veterinary practices to treat and control livestock diseases is an old practice in a large part of the world, particularly developing countries where animal health service facilities are still very poor or/and are found scarcely located at urban areas (Mc-Corkle, 1995; Sinha et al., 2002; Fiseha Mesfin, 2010). Even still, those in close proximity to conventional drugs also use traditional medicinal drugs to treat their animals due to shortage of modern drug of choice, cultural acceptability, efficacy against certain diseases and economic affordability (Woketole Gemechu et al., 1997; Tilahun Teklehaymanot and Mirutse Giday, 2007).

The studies conducted on ethno-veterinary medicinal plants in Ethiopia are very limited when compared with the multiethnic cultural diversity and the diverse flora of the country (Mirutse Giday et al., 2009; Firaol Tamiru et al., 2013; Tadesse Birhanu and Dereje Abera, 2015). Even though traditional ethno-veterinary knowledge of medicinal plants is very crucial to treat different animal diseases, there is no well documented information on this regard in Harari Regional State, Eastern Ethiopia. Thus, the present study was designed to identify and document ethno-veterinary medicinal plant species and traditional medicinal knowledge of the traditional health practitioners in study area. 


\section{Materials and Methods Study area}

The survey was conducted from November 2014 to April 2015at selected four districts of Harari Regional State, Eastern Ethiopia (Erer, Kille, Direteyara and Hakim). The districts are located at $512 \mathrm{kms}, 523 \mathrm{kms}$ and $510 \mathrm{~km}$ from east of Addis Ababa, the capital city of the country respectively. It is located at latitude and longitude of $9.1^{\circ} \mathrm{N} 42.3^{\circ} \mathrm{E} / 9.23^{\circ} \mathrm{N} 42.16^{\circ} \mathrm{E}$ and an elevation of 1500 meters above sea level. The average annual temperature of the area is $16.25^{\circ} \mathrm{C}$ (NMSA, 2015). The settlement pattern of the region is different from other regions of the country where $62 \%$ of the population reside in urban area. Mixed crop and livestock farming system is the mode of Agriculture in the region with cattle and shoats as the major livestock kept which are highly important for the livelihood of the local population in the rural areas of the regions. There is no adequate veterinary service in the area (CSA, 2009). The common plant species in the area include Flacourtiain dicamerr, Grewiabicolar, Solaniumincanum Ricinuscommunis, Coffeaarabica, Momrrdicafoetidaschumach, Justiciaschempriana, Prunusafricana, Crotonmacrostachyus, Phytolaceadodecandra and Colocasiaesculenta (HRAO, 2015).

\section{Study participants}

The study participants were voluntary knowledgeable elders and traditional healers who varied with age, sex, marital status, occupation, educational level and location.

\section{Sampling methods}

Purposive sampling technique was used to select the study districts based on the availability of practice of traditional medicine and on the recommendations of elders, religious leaders and local authorities. Moreover, the agro-climatic zones were considered to select the districts. Semi-structured questionnaires (interviews), field observations and group discussion were used to collect indigenous knowledge of traditional healers and knowledgeable elders about ethno-veterinary medicinal plants used for treatment of livestock diseases and disease conditions in which study subjects were selected purposefully. Nine kebeles (Erer Ulanula, ErerAbdullo, Erer Walda, Sofi, Kile, Dire Makora, Hakim, Dire Teyara and Hundane) were selected out of 36 kebeles of the region. Those kebeles which have almost similar climatic conditions with other neighboring 
kebeles were not included in the study and this is also additional factor for site selection.

\section{Ethno botanical data collection}

Selection of informants: A total of 21 key informants were selected from ethnic groups of different ages (28-81 years) with the help of Clan leader, local elders, agricultural and health extension workers and administrative personnel. The selected healers were well-known in the community due to their long practice in providing services related to traditional health care to the community. Prior to the interview process, discussion was held with the informants through assistance of clan leader and local elders to elaborate the objective of the study. This was done to clarify the purpose and build confidence of the respondents to provide reliable information without suspicion.

Semi-structured interviews: Semi-structure interview was prepared and done as described by Martin, 1995 and Cotton, 1996. Semi structured interviews ensured that there was a checklist of issues and areas to be discussed. During the interview, new and more ideas were raised that were necessary for the collection of the data.

Field observation: Field observation on the study sites including the market survey was done with the help of local guide and interpreter. At the time of observation, important points including culture of the community, market value and cultivation practices of the medicinal plants were recorded.

Group discussion: This was made at purposely selected nine study kebeles that had livestock with an estimated number of 3-5 community members which composed different groups that included one traditional healer in each kebeles where the discussion took place prior to ethno botanicals data collection. At the time of discussion ethno medicinal knowledge was gathered from the residence and knowledgeable members of the community and recorded carefully.

Guided field walk: The informant's had come together with the researcher to the origin of the plants where they are growing and provide local names. Then after, a particular medicinal plant species were collected with all ethno botanical data. 
Market survey: The survey was made to distinguish and record the type of herbal drugs sold in the market, and the multipurpose role of some medicinal plants was observed. Furthermore, herbal drug sellers and others who brought plant species were interviewed.

Informant consensus: In order to confirm the reliability of the information each informants was contacted at least twice and if the responses that were given at different time contradict to each other, they were considered to be unreliable and were rejected or reliability of the information can be confirmed by similar information given by different informants on the same issue.

\section{Plant specimen collection and identification}

The collected plant species with the necessary recorded information both from wild and home gardens based on the report of the informants. The plants were taken to the Herbarium of Biology Department of Haramaya University to identify and give scientific name using taxonomic keys form the volumes of the Flora of Ethiopia and Eritrea (Edwards et al., 2000; Hedberg et al., 2006) and by making a comparison with the already identified specimens.

\section{Data analysis}

Proportions (percentiles) and tables were used to summarize the collected ethno-veterinary medicinal data.

\section{Ethical approval}

This study was approved by the Research Review Ethical Board of Wollega University. The confidentiality of traditional property owners was completely maintained during processing of our data. In addition, all data from this study were not shared with third party out of researchers. Informed consent was also obtained from the participants to ensure their willingness. 


\section{Results}

\section{General characteristic of the informants}

A total of 21 key informants: traditional healers 10 (47.6\%), herbal drug seller $5(23.8 \%)$, knowledgeable elders, 6(28.57\%) were participated in the study. Males were accounted for the highest number which was 15 (71.4\%) and females were $6(28.6 \%)$ (Table 1$)$.

Table 1: General characteristic of the informants (n=21).

\begin{tabular}{|c|c|c|c|}
\hline Variables & & No of respondent & Percent (\%) \\
\hline \multirow[t]{2}{*}{ Sex } & Male & 15 & 71.4 \\
\hline & Female & 6 & 28.6 \\
\hline \multirow[t]{2}{*}{ Age } & Young & 4 & 19.0 \\
\hline & Elder & 17 & 81.0 \\
\hline \multirow[t]{2}{*}{ Educational status } & Illiterate & 11 & 52.4 \\
\hline & Literate & 10 & 47.6 \\
\hline \multirow[t]{2}{*}{ Marital status } & Married & 19 & 90.5 \\
\hline & Single & 2 & 9.50 \\
\hline \multirow[t]{3}{*}{ Group of Interviewer } & Traditional healers & 10 & 47.6 \\
\hline & Herbal drug seller & 5 & 23.8 \\
\hline & Knowledgeable Elder & 6 & 28.6 \\
\hline Total & & 21 & 100 \\
\hline
\end{tabular}

\section{Sources and availability of medicinal plants}

The source of most medicinal plants were from the wild (54.4\%) followed by home gardens (23.9\%) and herbal drugs sellers (21.7\%).Concerning the availability of the plants, majority of them were available every time $(69.6 \%)$, some are found seasonally $(21.7 \%)$ and the rest were difficult to get $(8.69 \%)$ as described in the study area (Table 2). 
Table 2: The source and availability of ethno-veterinary medicinal plant remedies used to treat livestock diseases in the study areas.

\begin{tabular}{llcc}
\hline Variables & & Frequency & Percent (\%) \\
\hline Source & Wild & 25 & 54.4 \\
& Domestic & 11 & 23.9 \\
& Market & 10 & 21.7 \\
Availability & Every time & 32 & 69.6 \\
& Seasonally & 10 & 21.7 \\
& Difficult to get & 4 & 8.7 \\
Total & & 46 & $100 \%$ \\
\hline
\end{tabular}

\section{Livestock diseases and disease conditions treated}

The informants were reported as there were 32 known livestock ailments/diseases are treated by traditional healers in the study area. Of the diseases/ disease conditions, black leg (18.75\%), Equine colic (15.62\%), retained fetal membrane (12.5\%), leech infestation (25\%) and pastuerellosis (12.5\%) were the most common one. Traditional healers (key informants) ranked these plant taxa based on their perception of the degree of effectiveness. Accordingly, Leucasdeflexahookf was rated the most effective in treating Black leg and followed by Ocimumlamifoliums (Table 3).

\section{Ethno-veterinary medicinal plant parts, habits used and mode of preparation}

The study showed that the widely used plant part for the preparation of the remedies was leaves (37.0\%) followed by roots (30.4\%) and the rest were fruits (6.53\%), seeds/pods (17.4\%), steam/bark (6.52\%) and whole part (2.17\%). Moreover, the habit of the plants used indicated that most of them were herbs (39.1\%) followed by tree (28.3\%). The informants had indicated as the highest mode of preparation was in the form of crushing (32.6\%) followed by chopping $(28.26 \%)$ and others like grinding, roasting, decoction and consumption of whole plant part (39.16\%). The study revealed that the condition of preparation of the remedies were majorly prepared from fresh material of the plants which accounted for $92.5 \%$ (Table 4 ). 


\section{Plant families frequently used among traditional healers}

About 46 plant species in 33 families were identified and documented based on the local claims of the plants in the study area. Among these plant families, Fabaceae and Solanaceae constituted the highest proportion (15.2\%) and (12.1\%), respectively (Table5).

Table 3: The number of ethno veterinary medicinal plant remedies used to treat livestock disease in the study area.

\begin{tabular}{llc}
\hline Local names of the diseases & Diseases treated & Frequency \\
\hline Abba gorba & Black leg & $6(18.8 \%)$ \\
Maadagubatte & Burn Wound & $1(3.12 \%)$ \\
Sareemarate & Rabies & $2(6.25 \%)$ \\
HafinsaDiilu & Retained fetal membrane & $4(12.5 \%)$ \\
Cinintoogara & Abdominal Pain & $4(12.5 \%)$ \\
Cinintookottedudda & Equine colic & $5(15.6 \%)$ \\
Goroorassa & Pastuerellosis & $4(12.5 \%)$ \\
Dhukkuba kale & Kidney disease & $3(9.37 \%)$ \\
Jiiggo/ dhitta'uguuruu & Mastitis & $2(6.25 \%)$ \\
Ciracha kale & Urolithiasis & $2(6.25 \%)$ \\
Bokoka & Bloating & $1(3.12 \%)$ \\
Goggaharcassa & Dermatophilosis & $1(3.12 \%)$ \\
Dhukkubafangasi & Fungal infestation & $2(6.25 \%)$ \\
Hinjiraanbeeylada & Lice infestation & $3(9.37 \%)$ \\
Abba sanga & Anthrax & $1(3.12 \%)$ \\
Maxxantootagarakeessa & GiT parasites & $5(15.6 \%)$ \\
Dhitessafulla & African horse sickness & $1(3.12 \%)$ \\
MaadessaAraba & Actinobacillosis & $1(3.12 \%)$ \\
MaxxantootaAala & Ecto parasite & $1(3.12 \%)$ \\
Gogginsagara & Constipation & $1(3.12 \%)$ \\
Goggaqunciss & Actinomycosis & $1(3.12 \%)$ \\
Cinninaboofa & Snake bite & $1(3.12 \%)$ \\
Rimeyyaderbu & Abortion & $2(6.12 \%)$ \\
Ceccebsahumna & Arthritis & $1(3.12 \%)$ \\
Lamsheysa & Paralysis & $1(3.12 \%)$ \\
Dhukkubigurra & Otitis & $2(6.25 \%)$ \\
Dhukkubiija & Conjuctivities & $1(3.12 \%)$ \\
Laguwalirrahinciitne & Irregular estrus and & $2(6.25 \%)$ \\
GafissaOkkolchisa & Lameness & $1(3.25)$ \\
\hline & Diarrhea & $3(9.37 \%)$ \\
\hline & &
\end{tabular}


Table 4: Summary of ethno veterinary medicinal plants, disease treated, habit, route, preparation and local, scientific and family name of the medicinal plants from November 2014 to April 2015

\begin{tabular}{|c|c|c|c|c|c|}
\hline Scientific name & $\begin{array}{l}\text { Family } \\
\text { name }\end{array}$ & Local name & Habit & Routes & $\begin{array}{l}\text { Indication and } \\
\text { preparation }\end{array}$ \\
\hline Croton macrostachyus & Euphorbiceae & Mekanisa & Tree & $\begin{array}{l}\text { Dermal and } \\
\text { orally }\end{array}$ & $\begin{array}{l}\text { The fresh leaf are } \\
\text { chopped then mixed with } \\
\text { honey Creamed and } \\
\text { applied in affected area } \\
\text { for } 3-5 \text { days (wound } \\
\text { healing, Fungal infection) }\end{array}$ \\
\hline AcacciaTortilis & Fabaceae & Tidacha & Tree & Orally & $\begin{array}{l}\text { The fresh root are } \\
\text { decoction with water and } \\
\text { Oil then drenching orally } \\
2-3 \text { bottle of coke cola for } \\
\text { 2-3days(Equine colic and } \\
\text { Abdominal pain) }\end{array}$ \\
\hline Celtisafricana & Ulmaceae & Cheka & Tree & Orally & $\begin{array}{l}\text { Fresh leaf are } \\
\text { chopped and bound } \\
\text { together with a leaf } \\
\text { of Caparisfascicularis } \\
\text { then mixed with } \mathrm{H} 2 \mathrm{O} \\
\text { drenching (Diarrhea and } \\
\text { GIT parasite). }\end{array}$ \\
\hline Mimusops Kummel & Sapotaceae & Bururi & Climber & Orally & $\begin{array}{l}\text { The fresh/dried bark are } \\
\text { decoction with Sugar } \\
\text { the Giving for (kidney } \\
\text { disease) 3-5cups of tea } \\
\text { for } 3-5 \text { days }\end{array}$ \\
\hline $\begin{array}{l}\text { JusticiaSchimperina(Ad } \\
\text { hatodaschimperiana) }\end{array}$ & Acanthaceae & Dumuga & Herbs & Externally & $\begin{array}{l}\text { The dried small pieces of } \\
\text { stem are tied and holding } \\
\text { on the neck (Otitis, } \\
\text { swollen of lymph node). }\end{array}$ \\
\hline Juniperusprocera & Cupressaceae & Gantirahabesha & Tree & Intravaginally & $\begin{array}{l}\text { The fresh fruits are } \\
\text { chopped and mixed } \\
\text { with vegetative oil then } \\
\text { infusion By bottle of } \\
\text { coke cola for 3-5daysn } \\
\text { (Abortion, irregular } \\
\text { estrus, postpartum } \\
\text { bleeding). }\end{array}$ \\
\hline $\begin{array}{l}\text { Oleaeuropae sub } \\
\text { sppcuspidata (Olea } \\
\text { Africana) }\end{array}$ & Dacaceae & Ejersa & Tree & $\begin{array}{l}\text { Dermal and } \\
\text { orally }\end{array}$ & $\begin{array}{l}\text { The bark and steam } \\
\text { are kept in the pot and } \\
\text { burying in the ground } \\
\text { with high power fire } \\
\text { then evaporating Oil are } \\
\text { creamed and drenching } \\
\text { (Arthritis, paralysis, back } \\
\text { bone pains). }\end{array}$ \\
\hline
\end{tabular}


Akil Usmane et al.,

\begin{tabular}{|c|c|c|c|c|c|}
\hline Scientific name & $\begin{array}{l}\text { Family } \\
\text { name }\end{array}$ & Local name & Habit & Routes & $\begin{array}{l}\text { Indication and } \\
\text { preparation }\end{array}$ \\
\hline Hageri abyssinica & Rosaceae & Heto & Tree & Orally & $\begin{array}{l}\text { The seed are grinding } \\
\text { and mixed with the } \\
\text { feed items like crop by } \\
\text { products } 2 \text {-3spoons for } \\
\text { 3days(GIT parasite) }\end{array}$ \\
\hline Ziziphusspinachristis & Rhamnaceae & Qurquressa & Herbs & Orally & $\begin{array}{l}\text { The fresh root are } \\
\text { crushed and mixed } \\
\text { with the crushed leaf of } \\
\text { Barleriaeranthemoides. } \\
\text { then mixed with water } \\
\text { 2-3glass of water for } \\
\text { 3-5days (Mastitis, } \\
\text { Abdominal pain). }\end{array}$ \\
\hline Barleriaeranthemoides & Acanthaceae & QumutoGaala & Herbs & Smoking & $\begin{array}{l}\text { The dried root are } \\
\text { crushed and mixed } \\
\text { together with the chopped } \\
\text { leafs of Nicotanatabacum } \\
\text { Then rolled like } \\
\text { Cigarettes and smoking } \\
\text { (RFM, Evil eye, Tooth } \\
\text { disease). }\end{array}$ \\
\hline Caparisfascicularis & Capporideae & Hidasare & Herb & Chewing & $\begin{array}{l}\text { The whole parts are } \\
\text { consumed by form of } \\
\text { chewing (RFM, Metritis). }\end{array}$ \\
\hline Caparissepiarialcommelina & Capporideae & Riga gange & Herbs & Orally & $\begin{array}{l}\text { The fresh leaf are } \\
\text { chopping and mixed } \\
\text { with honey drenching } \\
\text { (Swollen body, Equine } \\
\text { colic) }\end{array}$ \\
\hline Commicarpussillatusmelkele & Nyctaginaceae & Kontoma & Herbs & Orally & $\begin{array}{l}\text { The fresh/dried roots are } \\
\text { decoction with the Sugar } \\
\text { drenching (Equine colic, } \\
\text { bloat). }\end{array}$ \\
\hline Cucumisdipsaleus & Cucurbitaceae & Haragoge & Herbs & $\begin{array}{l}\text { Dermal and } \\
\text { Orally }\end{array}$ & $\begin{array}{l}\text { The fresh fruit are } \\
\text { crushed and mixed } \\
\text { with the leaf of } \\
\text { cucumisdipsaleus then } \\
\text { creamed on the bitten } \\
\text { body and drenching } \\
\text { (snake bite, rabies). }\end{array}$ \\
\hline Menthaspicata & Lamiaceae & Nana kuti & Herbs & Orally & $\begin{array}{l}\text { The fresh leaf is decoction } \\
\text { with tea (Irregular } \\
\text { Oestrus). }\end{array}$ \\
\hline Ficussycomorus & Moraceae & Lugo & Shrub & Dropping & $\begin{array}{l}\text { The fresh roots are } \\
\text { chopped and mixed with } \\
\text { goat milk then filtered } \\
\text { dropping } 1-2 \text { for five days } \\
\text { (Otittis, conjunctivitis). }\end{array}$ \\
\hline Acacia senegali & Fabaceae & Subansadima & Shrubs & $\begin{array}{l}\text { Dermal and } \\
\text { orally }\end{array}$ & $\begin{array}{l}\text { The seed are grinding } \\
\text { and mixed with Oil } \\
\text { \&milk then creamed and } \\
\text { drenching (Mastitis). }\end{array}$ \\
\hline
\end{tabular}




\begin{tabular}{|c|c|c|c|c|c|}
\hline Scientific name & $\begin{array}{l}\text { Family } \\
\text { name }\end{array}$ & Local name & Habit & Routes & $\begin{array}{l}\text { Indication and } \\
\text { preparation }\end{array}$ \\
\hline $\begin{array}{l}\text { Asparagus } \\
\text { leptoclododiuschiov }\end{array}$ & Asparagaceae & Kelamsare & Shurbs & Oronasally & $\begin{array}{l}\text { The root are roasted } \\
\text { powdered and decoction } \\
\text { drenching (kidney } \\
\text { disease). }\end{array}$ \\
\hline Acacia brevispica harms & Fabaceae & Ajoo & Shrubs & Orally & $\begin{array}{l}\text { The fresh root is decoction } \\
\text { and mixed with butter } \\
\text { drenching (Abdominal } \\
\text { pain). }\end{array}$ \\
\hline Opuntiaticusindica & Lactaceae & Tini & Shrubs & Dermal & $\begin{array}{l}\text { The fresh leaf are } \\
\text { chopped and mixed with } \\
\text { ash creamed (Fungal } \\
\text { infection). }\end{array}$ \\
\hline Withaniasomnitera & Solanaceae & Mixmixa & Herbs & Orally & $\begin{array}{l}\text { The fresh/dried seed are } \\
\text { grinding and mixed with } \\
\text { food (black leg, increasing } \\
\text { milking). }\end{array}$ \\
\hline Echinopskeberichamesfini & Echinopaceae & Qoromicho & Shrubs & Orally & $\begin{array}{l}\text { The fresh root are } \\
\text { crushed and together } \\
\text { with the chopped leaf of } \\
\text { Celtisafricana then mixed } \\
\text { with water drenching the } \\
\text { 3-5 water glass (Diarrhea, } \\
\text { Black leg). }\end{array}$ \\
\hline Vernoniamygdalina & Asteraceae & Ebicha & Tree & Orally & $\begin{array}{l}\text { The fresh leafs are } \\
\text { concoction and mixed } \\
\text { with salt solution } \\
\text { drenching (GIT parasite, } \\
\text { Diarrhea, Black leg). }\end{array}$ \\
\hline Maesallanceolataforssk & Myrsinaceae & Abayi & Tree & Nasorally & $\begin{array}{l}\text { The seed are grinded } \\
\text { and mixed with milk } \\
\text { drenching (Diarrhea, } \\
\text { blackleg). }\end{array}$ \\
\hline Flacourtiaindicamerr & Flacourticaceae & Waqaleyti & Tree & Orally & $\begin{array}{l}\text { The fresh leaf are } \\
\text { chopped and mixed } \\
\text { with water drenching } \\
\text { (Pastuerellosis). }\end{array}$ \\
\hline Hypericumrevolutumvahil & Hypericaceae & Unknown & Tree & Orally & $\begin{array}{l}\text { The fresh root are } \\
\text { crushed and mixed } \\
\text { with the vegetative } \\
\text { oil drenching (RFM, } \\
\text { Metritis). }\end{array}$ \\
\hline Ekebergiacapensissparm & Meliaceae & Mukaraso & Tree & $\begin{array}{l}\text { Oral and } \\
\text { dermal }\end{array}$ & $\begin{array}{l}\text { The fresh root are } \\
\text { decoction and mixed with } \\
\text { sheep/goat milk then } \\
\text { rubbed on bitten body } \\
\text { (Rabies, rabid animals). }\end{array}$ \\
\hline Ricinuscommunis & Euphorbiaceae & Kobo & Tree & Orally & $\begin{array}{l}\text { The fresh/dried fruit } \\
\text { are crushed and mixed } \\
\text { with atella drenching } \\
\text { (Blackleg, Actinomycosis). }\end{array}$ \\
\hline
\end{tabular}


Akil Usmane et al.,

\begin{tabular}{|c|c|c|c|c|c|}
\hline Scientific name & $\begin{array}{l}\text { Family } \\
\text { name }\end{array}$ & Local name & Habit & Routes & $\begin{array}{l}\text { Indication and } \\
\text { preparation }\end{array}$ \\
\hline Rhammusprina ides & Rhamnaceae & Geshe & Herbs & $\begin{array}{l}\text { Oral and } \\
\text { Dermally }\end{array}$ & $\begin{array}{l}\text { The fresh leaf are } \\
\text { crushed and together } \\
\text { with the chopped leaf } \\
\text { of Nicotanatabacum } \\
\text { then mixed with water } \\
\text { drenching (Leech } \\
\text { infestation). }\end{array}$ \\
\hline Partulacaoleracea & Portulaceae & Marare hare & Herbs & Orally & $\begin{array}{l}\text { The fresh/ dried are leaf } \\
\text { chopped and mixed with } \\
\text { Oil drenching (Gastritis, } \\
\text { Constipation). }\end{array}$ \\
\hline Lepidumsativum & Brassicaceae & Balakajis & Herbs & Orally & $\begin{array}{l}\text { The fresh leaf ischopped } \\
\text { mixed with water } \\
\text { drenching (Black leg). }\end{array}$ \\
\hline Mornorlicafoetidschumach & Zucurbitaceae & Firibofa & Herbs & Orally & $\begin{array}{l}\text { The fresh leaf are crushed } \\
\text { and mixed with salt } \\
\text { solution drenching (GIT } \\
\text { parasite). }\end{array}$ \\
\hline Solanumanguivicam & Solanaceae & Robanjireyti & Shrubs & Dermal & $\begin{array}{l}\text { The dried leaf are } \\
\text { crushed and mixed with } \\
\text { the butter creamed on } \\
\text { udder and teat (Mastitis). }\end{array}$ \\
\hline Solomumincanum & Solanaceae & Unknown & Shrubs & Orally & $\begin{array}{l}\text { The fresh leafs are } \\
\text { chopped drenching with } \\
\text { water (Pastuerellosis). }\end{array}$ \\
\hline Nicotanatabacum & Solanaceae & Tambo & Shrubs & Nasorally & $\begin{array}{l}\text { The fresh leafs are } \\
\text { crushed and together } \\
\text { with the chopped leaf of } \\
\text { Ricinuscommunis mixed } \\
\text { with oil drenching (Leech } \\
\text { infestation). }\end{array}$ \\
\hline Urerahypselodendronwedd & Urticaceae & Sakiyee & Shrubs & Orally & $\begin{array}{l}\text { The fresh/dried root are } \\
\text { crushed and mixed with } \\
\text { water drenching (RFM, } \\
\text { Abortion). }\end{array}$ \\
\hline Calpumiaaureaenth & Fabaceae & Hiddibuda & Shrubs & Dermal & $\begin{array}{l}\text { The seed are crushed and } \\
\text { mixed with vegetative } \\
\text { oil creamed and } \\
\text { drenching (Pastuerellosis, } \\
\text { Dermatophilosis, and } \\
\text { Ectoparasite). }\end{array}$ \\
\hline Sennadidymobotiyairwin & Fabaceae & Sanamaki & Climber & Orally & $\begin{array}{l}\text { The fresh leafs are } \\
\text { decoction and mixed } \\
\text { with goat milk drenching } \\
\text { (AHS). }\end{array}$ \\
\hline Ipomeaspp & Convolvulaceae & Dobale & Climber & Orally & $\begin{array}{l}\text { The fresh leaf are crushed } \\
\text { and mixed with water } \\
\text { Drenching(Actinomycosis) }\end{array}$ \\
\hline
\end{tabular}




\begin{tabular}{|c|c|c|c|c|c|}
\hline Scientific name & $\begin{array}{l}\text { Family } \\
\text { name }\end{array}$ & Local name & Habit & Routes & $\begin{array}{l}\text { Indication and } \\
\text { preparation }\end{array}$ \\
\hline Periplocalinearifocia & Asclepiadaceae & DigaloBururi & Herbs & Orally & $\begin{array}{l}\text { The dried bark are } \\
\text { decoction with tea } \\
\text { drenching(Kidney } \\
\text { disease). }\end{array}$ \\
\hline Chenopodiumambrosioides & Chenopodiaceae & Zeferana & Herbs & Orally & $\begin{array}{l}\text { The dried root are } \\
\text { decoction with water } \\
\text { drenching (Equine colic). }\end{array}$ \\
\hline Leucasdeflexahookf & Lamiacaceae & Wasima & Herbs & Orally & $\begin{array}{l}\text { The fresh root are } \\
\text { crushed and mixed with } \\
\text { H2O drenching (GIT } \\
\text { parasite). }\end{array}$ \\
\hline Rutachalepensish & Rutaceae & Martess & Herbs & Orally & $\begin{array}{l}\text { The fresh/dried leaf are } \\
\text { crushed andmixed with } \\
\text { vegetative oil Drenching } \\
\text { (Blackleg, Anthrax). }\end{array}$ \\
\hline $\begin{array}{l}\text { Monopsisstelleroides } \\
\text { verb }\end{array}$ & Lobeliaceae & Tobe & Herbs & Orally & $\begin{array}{l}\text { The fresh root are coasted } \\
\text { and mixed with } \mathrm{H} 2 \mathrm{O} \\
\text { drenching (GIT parasite). }\end{array}$ \\
\hline Ocimumlamifolium & Lamifolium & Damakase & Herbs & Orally & $\begin{array}{l}\text { The fresh leaf are crushed } \\
\text { and mixed with Atela } \\
\text { drenching (Black leg). }\end{array}$ \\
\hline Momorrdicafoetidaschumach & Cucurbitaceae & Suke & Herbs & Orally & $\begin{array}{l}\text { The fresh/dried leafs are } \\
\text { decoction with tea \&sugar } \\
\text { drenching (lameness, } \\
\text { Abdominal pain). }\end{array}$ \\
\hline
\end{tabular}


Akil Usmane et al.,

Table 5: Plant families frequently used by traditional healers and sold in herbal drug shop at Harari Regional State

\begin{tabular}{|c|c|c|}
\hline Family name & $\begin{array}{l}\text { No. of ethno-veterinary medicinal } \\
\text { plant species }\end{array}$ & Percent (\%) \\
\hline Ulmaceae & 1 & 3.03 \\
\hline Sapotaceae & 1 & 3.03 \\
\hline Meliaceae & 1 & 3.03 \\
\hline Brassicaceae & 1 & 3.03 \\
\hline Cupressaceae & 1 & 3.03 \\
\hline Fabaceae & 5 & 15.2 \\
\hline Solanaceceae & 4 & 12.1 \\
\hline Dacaceae & 1 & 3.03 \\
\hline Euphorbiaceae & 2 & 6.06 \\
\hline Asteraceae & 1 & 3.03 \\
\hline Myrsinaceae & 1 & 3.03 \\
\hline Cuccurbitaceae & 2 & 6.06 \\
\hline Flacourticaceae & 1 & 3.03 \\
\hline Hypericaceae & 1 & 3.03 \\
\hline Nyctaginaceae & 1 & 3.03 \\
\hline Acanthaceae & 2 & 6.06 \\
\hline Portucaceae & 1 & 3.03 \\
\hline Zucurbutaceae & 1 & 3.03 \\
\hline Moraceae & 1 & 3.03 \\
\hline Chemopodiaceae & 1 & 3.03 \\
\hline Rutaceae & 1 & 3.03 \\
\hline Lobeliaceae & 1 & 3.03 \\
\hline Rhamnaceae & 2 & 6.06 \\
\hline Cappordiceae & 2 & 6.06 \\
\hline Lamiaceae & 2 & 6.06 \\
\hline Ranuncullaceae & 1 & 3.03 \\
\hline Lamifolium & 1 & 3.03 \\
\hline Asparagaceae & 1 & 3.03 \\
\hline Lactaceae & 1 & 3.03 \\
\hline Echinopaceae & 1 & 3.03 \\
\hline Urticaceae & 1 & 3.03 \\
\hline Convolvulaceae & 1 & 3.03 \\
\hline
\end{tabular}




\section{Paired comparison}

A paired comparison was made for five medicinal plants which were used to treat equine colic in the study area. For this, 10 key informants traditional healer were requested to rank these plant taxa according to their experience and effectiveness. Accordingly, Commicarpussillatusmelkele stood first and followed by Acacciatortilis (Table 6).

Table 6: Paired comparison of ethno veterinary medicinal plants for treating of equine colic

\begin{tabular}{lllc}
\hline Scientific name & Family name & Local name & No. of Informants \\
\hline Commicarpussillatusmelkele & Nyctaginaceae & Kontoma & 9 \\
Acacciatortilis & Fabaceae & Tidacha & 8 \\
Caparissepiarialcommelina & Capporideae & Riga gangee & 6 \\
Rhammusprnaide & Rhamnaceae & Geshe & 5 \\
Rutachalepensish & Rutaceae & Martass & 4 \\
Total & & & 10 \\
\hline
\end{tabular}

The finding of the study revealed that agricultural expansion (24.3\%) has been found to be the first main threat for the plants followed by overgrazing (22.4\%) and the draught (10.7\%) in the study area (Table 7).

Table 7: Priority ranking of factors perceived as threat to ethno-veterinary medicinal plants based on the level of destructive effects in Harari Regional State based on interviews $(n=21)$

\begin{tabular}{lccc}
\hline Threats & Frequency & Percent (\%) & Rank \\
\hline Agricultural expansion & 25 & 24.3 & 1 \\
Overgrazing & 23 & 22.3 & 2 \\
Soil erosion & 18 & 17.5 & 3 \\
Deforestation & 17 & 16.5 & 4 \\
Drought & 11 & 10.7 & 5 \\
Low cultivation & 9 & 8.74 & 6 \\
Total & 103 & 100 & \\
\hline
\end{tabular}

\section{Transfer of knowledge about the plants}

According to this plant survey, the traditional systems and religious beliefs that generally restrict the way of transferring indigenous knowledge might 
have constrained, to some extent, the free flow of information on medicinal plants in this study. The highest number of transfer of knowledge of traditional medicine is to trusted eldest son that accounted for (36\%) followed by trusted sons (25.5\%), and others are all members of the family (18.5\%), relatives (12\%), and friends (8\%). The findings of the study showed that as people become older and older their knowledge of traditional medicine becomes better and better. In the study area, some traditional healer were licensed and some herbal drug shop were licensed to sell some medicinal plants for their customer or traditional healer although secretly sell some medicinal plant in the market and homes. Some of the plant medicines that grow in home gardens and sold are Rhammusprinaides, Allium sativum, Nicotianatabacum, Acacciatortili, Rutachalepensish and Commicarpussilla tusmelkele.

\section{Conservation to medicinal plants}

The study indicated that many of the informants who have knowledge on traditional medicine usage give priority to the immediate use of the medicinal plants than to its sustainable future uses, as a result their harvesting style is destructive. However, some plants have been protected for their spiritual and cultural purposes. Thus, these places are good sites for the protection of these medicinal plants since cutting and harvesting are not allowed in such particular areas. The plant species such as Allium sativum, Commicarpussillatusmelkele, Acacciatortilis and Rhammusprinaides are cultivated in or near the vicinity. This was indicated that a good practice for the conservation of medicinal plants through cultivation.

\section{Discussion}

In this study, a total of 46 ethno-veterinary medicinal plant species belonging to 33 families were documented with details on their local name, family, habit and traditional preparation, mode of application. Fabaceae and Solanaceae families constituted the highest proportion. The use of traditional medicine and medicinal plants in most developing countries as a normative basis fence of good health has been widely observed (Oudessa Kerro and Fiseha Tarreke, 2003). Although the importance of traditional medicine in primarily health care of livestock for the community of the study site is higher, but there is misunderstanding on the traditional medicinal knowledge and practices especially by the young generation and some modern health professionals that they completely ignore as if it was hundred percent harmful. However, the 
study revealed that traditional medicine is crucial to the community because, it is the only means of remedy especially for those who are far from the town where modern health facilities are relatively not available (Getachew Addis et al., 2001; Tilahun Teklehaymanot and Mirutse Giday, 2007).

The study revealed that the major portion of the farmers in the villages relies on traditional veterinary knowledge, practices and locally available materials (Mirutse Giday and Gobena Ameni, 2003) primarily medicinal plants to cure and prevent livestock health problems although other local materials are used, the use of plants for the treatment of various ailments prevails. In this study, herbaceous medicinal plants were the widely used for the treatment of various ailments constituting the largest percentage (80\%) which agree with studies in other parts of Ethiopia (Tamiru Tessema et al., 2001; Tadesse Birhanu et al., 2014).

The study was also indicated that the majority of the traditional healers were elder age groups (92\%). In comparison of educational status, non-educated informants handled much knowledge of traditional medicine whereas educated informants had low knowledge of traditional medicine, which is an indicative of impact of modern education. This was similar with report of Giday Yirga et al. (2012) and Haile Yigezu et al. (2014) in Jimma Zone, Tadesse Birhanu et al. (2014) from Horro Guduru Wollega distinct, west Ethiopia. The findings was also agrees with reports of Firaol Tamiru et al. (2013) at Dabo Hana district, West Ethiopia and GebreMedhin Gebrezgabiher et al. (2013) in Tigray Region. Less medicinal knowledge in relation to young age might be attributed to the fact that traditional knowledge is built with years of experience and transfer of medicinal plants knowledge follows vertical transfers to the most selected family member orally with great secrete from generation to generation usually at old age (Tadesse Birhanu and Dereje Abera, 2015).

The identified medicinal plants were comprised of mainly herbs (39\%) in the study area which was in line with other findings that were conducted by Tilahun Teklehaymanot and Mirutse Gidey (2007) in Northwest Ethiopia. Other studies conducted by Tamiru Tessema et al. (2001) in Ethiopia showed similar results. The dominance of herbs in the identified medicinal plants could have a negative implication since their growth could easily be hampered by recurrent drought which is common in all studied sites. According to this finding, the plant parts highly used for the preparation of the remedies were leaves (37\%) 
followed by roots (30.4\%). This finding agrees with those reported by Mirutse Giday et al. (2003) and Fisseha Mesfin (2007). According to this study the preferred condition for the preparation of remedies was fresh (82.5\%) followed by fresh/dry (17.5\%). In contrast to this idea, some professional traditional healers sell their plant medicines in dried form in the market and also store the dried plant medicines in different containers in their homes (Kebu Balemie et al., 2004).

The end product preparations of the traditional medicinal remedies were commonly in the form of crushing followed by chopping and decoctions. The results of the study also showed that the plant remedies were commonly administered orally followed by topical application. This study agrees with similar studies elsewhere in Ethiopia (Tadesse Birhanu and Dereje Abera, 2015). With regard to the dosage given to patients, there is no strictly standardized doses of herbal preparations as known for modern veterinary medicine were reported by traditional healers for any of the preparations used to treat livestock ailments in the study areas. But, higher dosage was given depend on the severity of the cases. The finding was similar with the study conducted by (Merga Bekana et al., 2004).

The findings revealed that the majority of the ethno-veterinary medicinal plants were mostly collected from the wild without cultivation followed by sold in market and home garden which is in line with another studies conducted in Ethiopia (Tesfaye Awas and Sebseb Demissew, 2009; Yared Yidezu et al., 2014). The fact that the remedies are found only in the wild possesses a big threat to their existence as long as the mass destruction of their habitats continues (KelbesaUrga et al., 2003; Haile Yineger et al., 2008). The study revealed that agricultural expansion was found to be the first main threat that destruct the plants followed by overgrazing in the study area (Sebsebe Demissew and Ermias Dagne, 2001; Fisseha Mesfin, 2007). The people of Harari Regional State have had a wealth of knowledge about traditional Veterinary Medicines for treating their livestock.

\section{Conclusion}

In this study, 46 species which belongs to 33 families of ethno-veterinary medicinal plants were identified in the study area. The plants were mainly collected from the wild by consultation of traditional healers. Among the threats, 
agricultural expansion and overgrazing were found to be the main threats for the medicinal plants. Thus, attention should be given to medicinal plants and further scientific research should be needed to determine safety, toxicity and dose of the medicinal plants in the study area.

\section{Acknowledgements}

The authors would like to thank Wollega University, School of Veterinary Medicine for logistic support, study participants and all individuals who render help during the study are highly acknowledged.

\section{References}

Addis, G., Dawit, A. and Urga, K., 2001. A survey of traditional medicinal plants in Shirka District Arsi Zone, Ethiopia. J. Ethiop. Pharmac., 19, 30-47.

Awas, T., 2007. Plant diversity in Western Ethiopia: Ecology, ethnobotany and conservation. PhD Dissertation, Faculty of Mathematics and Natural Sciences, University of Oslo, Norway.

Awas, T. and Demissew, S., 2009. Ethnobotanical study of medicinal plants in Kafficho people south western Ethiopa. In: Proceeding of the $16^{\text {th }}$ International Conference of Ethiopian Studies. 711-726: (Ege, Aspen, S., Birhanu, H., Tefera and Shiferaw Bekele Ed.) Trondheim, Norway.

Balemie, K., Kelbessa, E. and Asfaw, Z., 2004. Indigenous medicinal plant utilization, management and their threats in Fentalle area eastern Shewa, Ethiopia. Ethiop. J. Biolo. Sci., 3, 37-58.

Bekana, M., Sori, T., Adugna, G. and Kelbessa, E., 2004. Medicinal plants in the ethnoveterinary practices of Borana pastoralists, Southern Ethiopia. Int. J. Aplres. Vet. Med., 2, 220-225.

Birhanu, T., Gadisa, M., Gurmesa, F. and Abda, S., 2014. Survey on ethno-veterinary medicinal plants in selected woredas of East Wollega Zone, Western Ethiopia. J. Biol. Agric. Health Care., 4(17), 97-105.

Birhanu, T. and Abera, D., 2015. Survey of ethno-veterinary medicinal plants selected Horro Gudurru districts western Ethiopia. Afr. J. Plant Sci., 9(3), 185-192.

Cotton, C.M., 1996. Ethno-botany: Principles and applications. John Wiley and Sons, Chichester, England: 347.

CSA, 2009. Central Statistical Agency: Federal Democratic Republic of Ethiopia. 
Demissew, S. and Dagne, E., 2001. Basic and applied research on medicinal plants of Ethiopia. In: conservation and sustainable use of medicinal plants in Ethiopia. 29-33, (Medhin Zewdu and Abebe Demissie, eds). In Proceedings of the National workshop on Biodiversity Conservation and Sustainable use of Medicinal plants in Ethiopia. IBCR, Addis Ababa.

Edwards, S., Mesfin, T., Sebsebe, D. and Hedberg, I., 2009. Magnoliaceae to flacourtiaceae. In: Flora of Ethiopia and Eritrea. The National Herbarium Addis Ababa, Ethiopia and Uppsala, Sweden.

Gebrezgabiher, G., Kalayou, S. and Sahle, S., 2013. An ethno-veterinary survey of medicinal plants in Woredas of Tigray region, Northern Ethiopia. Int. J. Biodivers. Conserv., 5(2), 89-97.

Gemechu, W., Girma, A., Temesgen, S. and Ensermu, K., 1997. Aspects of farmers' knowledge, attitudes and practices (KAP) of animal health problems in the central highlands of Ethiopia. Presented at International Conference Ethnovet. Med. Pune, India.

Giday, M. and Ameni, G., 2003. An ethnobotanical survey on plants of veterinary importance in two woredas of Southern Tigray, Northern Ethiopia. Ethiop. J. Sci., 26 (2), 123-136.

Giday, M., Teklehaymanot, T., Animut, A. and Mekonnen, Y., 2007. Medicinal plants of the Shinasha, Agew Awi and Amhara peoples in North West Ethiopia. J. Ethno. Pharmacol., 110, 516-525.

Giday, M., Asfaw, Z. and Woldu, Z., 2009. Medicinal plants of the Meinit ethnic group of Ethiopia: An ethnobotanical study. J. Ethnopharmacol., 124, 513-521.

Hedberg, I., Kelbessa, E., Edwards, S., Demissew, S. and Persson, E., 2006. Gentianaceae to cyclocheiaceae. In: Flora of Ethiopia and Eritrea vol.5. The National Herbarium Addis Ababa, Ethiopia and Uppsala, Sweden.

HRAO, 2015. Annual report on population size and agriculture of the Harari Regional state. Eastern, Ethiopia.

Kerro, O. and Tareke, F., 2003. Bovine mastitis in selected areas of southern Ethiopia. Trop. Anim Health Prod., 35, 197-205.

Martin, G.J., 1995. Ethnobotany: A method Manual. Chapman and Hall, London. Medicine in Ethiopia: Prospective and Development Efforts. In: Ethiopian Pharmaceutical Association. 45-53 (Tamirat Ejigu, edn.) Silver Jubilee Anniversary, Special Issue. Addis Ababa, Ethiopia. pp. 265-270.

McCorkle, C.M., 1995. Back to the future lessons from ethno-veterinary research, development, extension for studying and applying knowledge. J. Agric. Food Hum. Values Soc., 22(2), 52-80. 
Mengistu, G., 2004. The effect of herbal preparations on staphylococcus aureus and streptococcus agalactiae isolated from clinical bovine mastitis (Unpublished MSC thesis Faculty of veterinary medicine, AAU).

Mesfin, F., 2007. An ethnobotanical study of medicinal plants in Wonago Woreda, SNNPR, Ethiopia. MSc thesis. Addis Ababa University. Addis Ababa.

NMSA, 2015. National Meteorology Service Agency: Monthly report on temperature and rainfall distribution for Harar Regional State, Eastern Ethiopia.

Schulz, V., Hansel, R. and Tyler, V., 2001. Rational phytotherapy. A physician's guide to herbal medicine. $4^{\text {th }}$ edition. Springer Verlag Berlin, Germany.

Sinha, P., Govil, N.J. and Singh, V.K., 2002. Diseases and their management, recent progress in medicinal plants, Sci. Tech. Pub LLC, USA, pp 1-105.

Tessema, T., Gidey, M. and Aklilu, N., 2001. Stacking and information on the medicinal plants of Ethiopia. In National Biodiversity Strategy and Action Plan Project Medicinal Plant Team, Addis Ababa: IBDA.

Tamiru,F., Terfa, W., Kebede, E., Dabessa,G., KumarRoy, R. and Sorsa, M., 2013. Ethno-knowledge of plants used in veterinary practices in Dabo Hana District, West Ethiopia. J. Med. Plant Res., 7(40), 2960-2971.

Teklehaymanot, T. and Giday, M., 2007. Ethnobotanical study of medicinal plants used by people in Zegie peninsula, north western Ethiopia. J. Ethnobiol. Ethnomed., 3, 12.

Teklehaymanot, T. and Giday, M., 2010. Ethnobotanical study of wild edible plants of Kara and Kewego semi-pastoralist people in Lower Omo River Valley, Debub Omo Zone,

Urga, K., Assefa, A. and Guta, M., 2003. WHO Country Office, Addis Ababa Ethiopia. Proceedings of a national workshop held in Addis Ababa, Ethiopia: (Ethiopian Health and Nutrition Research Institute, Addis Ababa, Ethiopia).

Yigezu, Y., Haile, D. and Yenet, W., 2014. Ethno-veterinary medicines in four districts of Jimma zone, Ethiopia: A cross sectional survey for plant species and mode of use. BMC Vet. Res., 10,76.

Yineger, H., 2005. A study of ethnobotany of medicinal plants and floristic composition of the dry Afromountain forest at Bale Mountains National Park. MSc thesis, Addis Ababa, Ethiopia.

Yineger, H., Kelbessa, E., Bekele, T. and Lulekal, E., 2008. Ethno-veterinary medicinal plants at Bale Mountains National Park, Ethiop. J. Ethnopharmacol., 112(3), 5570. 
Akil Usmane et al.,

Yirga, G., Teferi, M., Gidey, G. and Zerabruk, S., 2012. An ethno-veterinary survey of medicinal plants used to treat livestock diseases in Seharti Samre district, Northern Ethiopia. Afr. J. Plant Sci., 6(3), 113-119. 